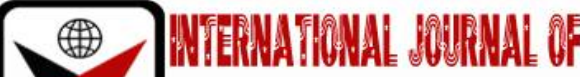

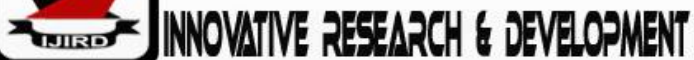

ISSN 2278-0211 (Online)

\section{Analysis of the Effectiveness of Tanzania National Youth Development Policy in Addressing Youth Unemployment: A Case Study of Dar es Salaam, Tanzania}

\author{
Emmanuel Selemani Shindika \\ Principal, Tanzania Public Service College (TPSC), Tanzania \\ Francis Daudi \\ Assistant Lecturer, Archbishop Mihayo University College of Tabora Tanzania
}

\begin{abstract}
:
This paper attempts to make analysis of the effectiveness of National Youth Development Policy 2007 in addressing the challenge of youth unemployment in Tanzania. This paper is a result of survey conducted in Dar es salaam City (Tanzania) with the intention of understanding the relevance of the policy thirteen years now after its formulation. The study focused on four areas, which are Mbezi Louis, Goba, Gongo la Mboto and Kinondoni. The survey shows that, NYDP 2007 is irrelevant to current youth unemployment in terms of strategies and magnitude of the challenge. Apart from that, during formulation of NYDP 2007 there was no considerable attention to baseline survey, gender relations and specified terms in addressing youth unemployment. Therefore, this paper, succinctly suggests that Tanzania's focus to become industrialized and middle-income country need youth policies and interventions which address the youth unemployment in a realistic way. This will open doors for decent incomes and propel the economy towards more equitable growth.
\end{abstract}

Keywords: National youth development policy 2007, youth unemployment, baseline survey, industrialized and middleincome country

\section{Introduction}

Unemployment being a global challenge, has been highly politicised and debated among the policy makers, researchers, politicians, social partners, business owners and other stakeholders who are considered as labour market agents. This is due to the fact that, Unemployment affects both developing and developed nations in the world.

According to the Plan International (year), youth are three times likely to be unemployed than adults, the projection that by next decade, not less than one billion youth will enter world labour market. Recent studies reveal that youth make 60 per cent of the unemployed population in Africa (Broecke et al., 2013). Therefore, some nations in the World, let alone Africa have formulated Youth Policy to address youth's problems with unemployment being the most significant part of these documents. This is key argument in this study whose main focus is on succinctly assessing the efficiency of Tanzania National Youth Development policy in addressing youth unemployment in Tanzania.

In Tanzania, Youth unemployment is viewed as next generation bomb whose explosion would lead to negative outcomes almost in all spheres of life including social, political and economic. Though Tanzania is political stable since independence but scholars analyse spread of Arab Spring in Arab Countries, Xhenophobia in South Africa and 2009 Riots in Uganda as the results of massive youth unemployment. A close look at the social and political riots one would notice unemployed youths as majority (Massa, 2014).

To address youth unemployment and other problems, the government of Tanzania has adopted different strategies in terms of programmes and policies such as National Youth Development Policy 1996 that was amended in 2007, National Youth Council Law 2015, National Strategy for Growth and Reduction of Poverty famously known as MKUKUTA I (2006-2010) and MKUKUTA II (2011-2015) and National Strategy for Youth Involvement in Agriculture 20162021.

Notwithstanding these mechanisms, little have been done to understand the success of mechanisms in reducing youth unemployment yet. , around 900,000 youth enter Tanzania's job market every year whilst formal sector create only 60,000 jobs (World Bank Report, 2018). Hence, this study is an attempt to analyse efficiency of National Youth Development policy 2007 in addressing youth unemployment in Tanzania.

\section{Research Design and Methodology}

This study employed both quantitative and qualitative research designs. Qualitative approach involves systematic observation, use of documentary review, in-depth interview and discursive analysis of data (Darlington, and Scott, 2002). 
According to Padgett (1998), the use of qualitative approach puts emphasis on quality than quantity. It pays attention to specific events and issues so as to gain deeper understanding of their meaning and significances. This study adopted qualitative approach to provide greater insight and in-depth analysis of National Youth Development Policy 2007 particularly in addressing youth unemployment in Tanzania. The approach was also employed in gathering data from Focused Group Discussions and Key Informant Interviews. On the other hand, quantitative approach was used to analyse statistical data from Youth Employment Report (2015), National Strategy for Youth Involvement in Agriculture (20162021) and other documents. The population for this study was both employed and unemployed youths, Youth leaders, representatives from civil society organisations and private sector organisations, Youth Member of Parliament, local leaders and respondents from relevant government ministries.These groups were involved in the study in order to grasp practical realities and experiences pertaining to youth unemployment and the way National Youth Development Policy 2007 is addressing the challenge.

\section{Study Area}

Though Unemployment is a challenge globally and Tanzania in particular, this study focused on four areas, which are Mbezi Louis, Goba, Gongo la Mboto and Kinondoni because of high population of youth who are unemployed. These areas attract youths from upcountry due to their accessibility to city centre in search for job, cheap food and accommodation. Many youth in those areas were involved part time jobs and petty business.

\section{Data Collection Methods and Data Analysis}

Data collection and data analysis was done simultaneously. Data collected from all sources were coded and categorized based on the research objectives. Moreover, Study employed thematic analysis which allows well-detailed and complex descriptions of collected data. The study also employed documentary analysis, key informants interviews and Focus group discussions.

\subsection{Documentary Review}

The study centred on Government of Tanzania National Youth Development Policy (2007) and other documents related to youth unemployment in Tanzania. The researcher also consulted policies, reports and manuals related to unemployment, youth unemployment and NYDP 2007 that were obtained from Ministry of State in the Prime Minister's Office (Responsible for Policy, Parliamentary Affairs, Labour, Employment, Youth and people with disabilities), Tanzania Public Service College, Civil society organisations, private sector organisations and Tanzania Bureau of Statistics.

\subsection{Focused Group Discussions}

Focus group discussions were asserted as an interview method where different types of respondents of the same characteristics simultaneously produce data on a specific issue (Chilisa and Preece, 2006). For this study, four groups were formed and each comprised of 15 youths who were either unemployed or in part time jobs in the selected areas. The first order of discussion was to develop discussion checklists of topics in order to ensure consistency and completeness in carrying the very discussion. This method was useful because responses given had highly valid due to the clarity of the context and details of the discussion. The method was applied to 60 respondents who gave their in-depth knowledge of the effectiveness of Tanzania's national youth development policy from different point of view.

\subsection{Key Informants Interviews}

Key Informants Interviews formed an important source of this study. The method was employed so as to allow a researcher to enter into respondents' perspectives. Focal persons were identified and selected purposively to act as key informants. In that way, twenty respondents were selected for Key Informants Interviews. They included four youth leaders, two respondents from civil society organisations, two from private sector organisations, three youth member of Parliament, four local leaders and five relevant government ministries.

\subsection{Questionnaire Method}

This study also used questionnaire method to collect data. The researcher prepared structured questionnaires comprised of open-ended questions that were used to in-depth information on youth unemployment. The method was applied to allow sufficient number of participants to be involved in this study.

\section{Literature Review}

\subsection{The Concept of 'Youth'}

The youth can be defined as young men and women from age group of 15 to 35 (Tanzania's Youth Development Policy, 2007). Other international organizations define youths depending on their policies and legislations. For instance, the Commonwealth Youth Programs define the youth as those in the age category of 16 to 29 while the United Nations refers to them as young men and women age of 15 and 24. Therefore, this demonstrates that there is no any fixed and universal accepted definition of youth on the basis of age. This has implications as governments and international organisations fail to have common understanding and strategies to tackle challenges which dwindle youths in an inclusive way. Indeed, this study suggests global harmonisations of the concept of Youth for an agreed ground to solve their problems. 


\subsection{Youth Unemployment in Tanzania}

Though it is known that Youth are vibrant resources of which if well harnessed can immensely contributed to the development of the country, yet the Tanzania's labour market cannot absorb a new working population generated from schools, colleges and university every year (Haji, 2015). This is major reason as to why youth unemployment remains a most debatable topic that had attracted scholars, policy makers, NGO's ${ }^{1}$, Youths, Government and People from all walks of life. The government of Tanzania have undertaken some mechanisms and strategies such as National Youth Development Policy 1996, National Youth Development Policy 2007, National Youth Council Law 2015, National Strategy for Growth and Reduction of Poverty famously known as MKUKUTA I (2006-2010) and MKUKUTA II (2011-2015) and National Strategy for Youth Involvement in Agriculture 2016-2021 but youth unemployment is still raising and leads to social crimes, dependencies and poor economic growth. In 2018, the World Bank reported that around 900,000 young people enter the Tanzania's job market annually, but only 50,000 to 60,000 formal sector jobs are created each year. It purports that more than $66 \%$ percent of the population is under the age of 25 years. The report implied that job shortage will keep rising annually unless job opportunities increase.

Raising of youth unemployment in Tanzania is largely associated with few available opportunities for paid work (ILO, 2012); high youth population growth versus under absorption by the labour market (Haji, 2015); and overdependence on government, education systems (Mjema, 1999). This study also find out, dependence on traditional sectors and inadequate of credit facilities designed for youths as other reasons which accelerates youth unemployment in Tanzania. Matter of fact is youths constitute more than 60 per cent of Tanzania's population. Therefore, this paper succinctly point out that Tanzania's move to become industrialized and middle-income country need youth policies and interventions which address the youth unemployment in a realistic way.

Tanzania has also adopted and implemented some structural reforms and interventions to support private sectors as way to combat youth's unemployment in the country. Apart from that, the government has formulated ministry responsible for youths issues (Ministry of State in the Prime Minister's Office-Responsible for Policy, Parliamentary Affairs, Labour, Employment, Youth and Disabled). Under His Excellence President John Joseph Pombe Magufuli, Youths empowerment loans were given which is four per cent of annual income of every local council in Tanzania. Other interventions includes funds and schemes such as Youth Development Fund -YDF, National Entrepreneurship Development Fund -NEDF, Agricultural Inputs Trust Fund -AGITF, Private Agricultural Sector Support Trust -PASS Trust, SME Credit Guarantee Scheme and Export Credit Guarantee Scheme -ECGS. Existing literatures suggests that, the national policies are important mechanisms to address youth's unemployment, health's issues, space in democracy and education. With regard to this study, focus will be on youth unemployment and role of National Youth Development Policy 2007.

\section{Research Findings}

\subsection{Review of NYDP 2007}

The NYDP 2007 asserts that, Youths represent the driving force behind socio-economic and political reforms as well as global changes. Thus, it gives importance for the inclusion of youths in building future of Tanzania as a nation. The matter of concern is to provide direction to youth, partners and stakeholders on issues exclusively related to youth development.

The NYDP 2007 gives summary of the policy in the background. It highlights different issues like unemployment, environment degradation, drug abuse, poverty and HIV/AIDS but there is no any attention given from beginning to insist or direct policy makers, government and other stakeholders on what to do to combat unprecedented increase of youth unemployment in Tanzania.

Though the Policy background addresses the dire need for employment among Tanzania's youth, there is no any analytical statement which offers a clear picture as to why youth have limited access to employment in Tanzania. The policy statements are too general as they based only on the traditional patterns of employment, employment and underemployment in any nations.

The policy was formulated by the make use of Population and Housing Census 2002 whereas Tanzania's Mainland had 33.58 million people and the total number of youth between 15 and 35 was 35 per cent of the population. According to Population and Housing Census (2012), about 77\% of the Tanzania's population is under the age of 35 years. This is an alarming situation for the need of new policy not just reviews of Policy which existed for almost thirteen years now.

The NYDP 2007 incorporated Integrated Labour Force Survey 2000/01 which statistically gave data on labour force, unemployment and imbalance between urban and rural areas. Though it clearly shows youth are vulnerable to problems associated with unemployment but there is nothing like reasons for the decline of new created jobs Vis-à-Vis high entrants. Furthermore, the document outlines the ways in which government of Tanzania is promoting employment creation such as

- Environment sustainability programs,

- Entrepreneurship skills training,

- Gender and equity programs,

- Education and

- Empowerment of youth. 
Actually, these ways for promoting employment creation were adopted from Poverty Reduction Strategy III Progress Report 2002. This make the document more patched work. Again, there is no critical analysis of these areas to avoid ambiguity and it does not make one (specifically) accountable for these ways.

The policy pointed out areas in which employment creation will be strategically focused:-

- Identification of priority sector for productive and decent work creation at all levels.

- Improved agriculture production, development of agro-industries, support to small and medium-scale enterprises, and expand labour intensive manufacturing.

- Conducting research to find out integration of traditional farming system and modern methods.

- Sectoral interventions in agricultural and industrial policies to ensure that growth are employment intensive.

- Provision of legal framework for mortgage lending. Skills training and job creation program to be linked directly to labour market demand and mechanisms.

- $\quad$ Establishing employment promotion fund to improve access to credits.

- Provision of employability skills through community services.

- Intensive technical and vocational education by learning from other countries.

- New investments or programs to be employment creation oriented.

- Encouraging the formation of youth development groups, Savings and Credit Cooperative Societies.

- Develop financial policy tools and support government promotion agencies located across the country.

One would expect these areas to be more dynamic by focusing on emerging sectors such as information communication technology and professional services. The document address agriculture and informal sector as the 'an interim measure' but in Tanzania, main challenge among youth is to find more productive jobs which provides decent incomes hence equality in economic growth of the country.

More than 75 per cent of Tanzania's youths are in agriculture which is traditional sector (TYVA, 2017). Only 15 per cent of working youths are in emerging sector which pays six times more than traditional sector jobs (Morisset \& Mahjabeen, 2014). It is expected that the overall domestic labour force in Tanzania will grow to 45 million by the year 2030, significant number will come from growth of the youth population whilst agriculture as traditional sector will only absorb small part of this growth.

Additionally, current graduates are considered as 'unfit' as they lack adequate skills demanded by employers. Thus, there is need of new policy which will take into consideration these issues and address them to tackle youth unemployment in Tanzania.

On 'Economic Situation' policy resonates 'self-employment' which absorb large part of youth in Tanzania and identify some problems not challenges such as lack of equipment, technology know-how and working capital. The section does not address gender imbalance in self-employment. It should be noted that, most of youth in Tanzania engage themselves in what is so called 'Self-employment' due to failure of entry to salaried work (Bridges et al., 2013). Female youth are three times likely to have chosen self-employment due to disproportionate household burdens and inaccessibility to social capital. Apart from that, young women-owned businesses that are smaller in scale less productive than male youth-owned business (Sabarwal \& Bardasi 2009; Rickers \& Costa, 2011). Issue of gender and unemployment challenges in Tanzania requires attention both in plans and policies.

Youths' unemployment is currently debatable among scholars, policy makers, stakeholders and youths themselves. The central point of the debate lay on effectiveness of the 2007's National Youth Development policy in addressing youth unemployment in Tanzania. According to Chachage (2009), the National Youth Development policy did not make a comprehensive review of National Youth Development policy 1996. Therefore, there is no need to review 2007's NYDP but to prepare a document that will fit excellently with the youth employment context in Tanzania.

Preparation of policy requires baseline study and African Youth Charter (AYC) which was African Uniono 2 July 2006 insists the need of baseline to understand youth's demands on different matters including employment. Unfortunately, whether intentionally or unintentionally, NYDP 2007 reveals that there was no baseline study carried out to ascertain the status of youth in Tanzania. Again, baselines which were conducted after 2007 are not part of NYDP 2007. Therefore, Youth unemployment as part of well-identified problems is not clearly reflected in the policy because it does not include the youth's demands from ground. Baseline study could fill existing gaps in addressing youth unemployment.

Therefore, this paper, succinctly suggests that Tanzania's focus to become industrialized and middle-income country need youth policies and interventions which address the youth unemployment in a realistic way. This will open doors for decent incomes and propel the economy towards more equitable growth.

\section{Data Presentation}

\subsection{General Profile of Respondents}

The survey was conducted in Dar es Salaam. Respondents who were involved Key Informants Interviews (KII), Focus group discussions (FGD) and filled 68 questionnaires in four selected areas such as Mbezi Louis, Gongo la Mboto, Goba and Kinondoni. These sources were deemed adequate for this survey. About $72 \%$ of the respondents were Male while 28 per cent were Female (See Table 2). The age category of 21-30 was majority in term of size averaging 51.5 per cent, followed by age category between $31-40$ which was 26.5 per cent (Table 2). Though in Tanzania youth age is between 15 and 35, but the survey involved respondents above 35 years to get their experiences and insights on NYDP 2007 which existed for 13 years now. The respondents above 35 years old seemed tired of NYDP 2007 and participating on surveys which have been conducted without new document or positive outcomes on empowering youths in Tanzania. 


\begin{tabular}{|c|c|c|c|}
\hline & Age & Frequency & Percentage \\
\hline 1 & $11-20$ & 1 & 1.5 \\
\hline 2 & $21-30$ & 35 & 51.5 \\
\hline 3 & $31-40$ & 18 & 26.5 \\
\hline 4 & $41-50$ & 9 & 13.2 \\
\hline 5 & $51-60$ & 4 & 6 \\
\hline 6 & $61-70$ & 1 & 1.5 \\
\hline
\end{tabular}

Table 1: Age Category Involved In Survey

\begin{tabular}{|c|c|c|c|}
\hline & Sex & Frequency & Percentage \\
\hline 1. & Male & 49 & 72 \\
\hline 2. & Female & 19 & 28 \\
\hline
\end{tabular}

Table 2: Gender Category involved in Survey

\subsection{Patterns of Employment}

The study found out that, more male youth are in employment compared to female youth across the youth age group. The study further noted that, female youth are practically absent from labour intensive works such as transportation, constructions and other. Female respondents involves more on food services, accommodation and small business. There are some reasons for the gender gap as the survey indicated, some of them are imbalance in access education, heavy burden of household duties which fall on female youth and inequality in accessibility of social and economy capital. Then, there is a need to find measures towards addressing gender imbalance in order to achieve the Sustainable Development Goals.

\subsection{Employment Status}

According to the analysis of the study, 85 per cent are employed, 15 per cent are not employed (Table 3). The largest proportion constituted 72.4 per cent of youths who are self-employed, while 8.6 per cent were employed either by government or private sectors. 19 per cent are engaged themselves on family owned business or projects (Table 4). The patterns shows the importance of government and other stakeholders to work for the growth number of youths who are engage on self-employment. The study found out that, the presence of some savings and credits schemes and youth's empowerment funds enables more youths to engage on their own income-generating activities. In addition to that, the FGD's denoted that there are other reasons which make more youths into self-employment such as lack of skills needed by employers, lack of networks 'not politically connected', lack of experience and inadequate education.

\begin{tabular}{|c|c|c|c|}
\hline & Status & Frequency & Per Cent \\
\hline 1. & Employed & $\mathbf{5 8}$ & $\mathbf{8 5}$ \\
\hline 2. & Not Employed & 10 & 15 \\
\hline
\end{tabular}

Table 3: Employment Status

\begin{tabular}{|c|c|c|c|}
\hline & Category & Frequency & Per cent \\
\hline 1 & Self Employed & 42 & 72.4 \\
\hline 2 & $\begin{array}{c}\text { Employed by Government or } \\
\text { Private Sectors }\end{array}$ & 5 & 8.6 \\
\hline 3 & $\begin{array}{c}\text { Engaged in Unpaid Family } \\
\text { work/business }\end{array}$ & 16 & 19 \\
\hline
\end{tabular}

Table 4: Job's Category

\subsection{Challenges Encountered in Search for Employment}

The interest of the researcher was to envisage the challenges that majority of the youth encounter during their search for jobs. The findings show that majority of youth (82\%) find it difficult to be employed because of lacking necessary skills. Furthermore, scrutiny of the findings indicate that most of the employers use 'experience' as the tool to remove youths from competition. From survey, 49 per cent of youths said 'experience' is not an obstacle but 'not being politically connected' as the obstacle. About $22 \%$ of the respondents were not sure whether experience limits their chance to be employed. It was also believed that the government has good programmes and intentions of empowering youth but there are challenges on implementers' majority of whom ignore the role of youth in economic development for national building mission.

Youths in the Focus Group Discussions (FGD) gives example of youth's empowerment loans which are interestfree from local councils. The local councils are responsible to allocate 4 per cent of their annual income for youths empowerment loans. Unfortunately, most of these local councils re-allocate the funds to other developmental activities. This kind of negligence which prevails among District Executive Directors that attribute youths' inaccessibility to employment with theory oriented education system. They proposed government to incorporate vocational and technical aspects in curriculum. 


\section{Tanzania Youth Development Policy 2007 and the Reality on the Ground}

The findings also revealed that majority of the respondents (80\%) reported that they have never seen the 2007's TYDP. Very few of them (7.3\%) read the document but they said it is 'outdated' and unqualified to be called National Policy. They further propose the adoption of inclusive approach in formulate a new document which will address well challenges posed by Science and Technology, Political and Economic systems, Education systems and unprecedented growth of youth's population in Tanzania.

This study found out that, the document is well analyzed by civil society and Non-Governmental Organizations. But majority of youths on ground are not even aware of existence of the policy 13 years now. Those who are aware of the policy do not have sense of ownership of this document.

It was also noted that, many NGO's and Civil Societies which claims to advocate youths issues have not taken any initiatives to make youth familiar with this policy. Accessibility to funds or loans from government and other financial institutions is greatly dwindled by the lack of clear policy. Youths appreciated efforts done by government and stakeholders yet a lot has to be done to ensure youths become center of industrial development. The study could not go further on political or other aspects as it beyond scope of this survey and objectives.

\section{Conclusion and Recommendations}

\subsection{Conclusion}

Youth unemployment problem in Tanzania is not a matter of have not job to do but of structural problems in accessing the decent income-generating activities. The study noted that there is need for entrepreneurial and vocational skills, allocation of enough resources and transparency in employment systems (discouraging internal job advertisements) and good policy that address unemployment and other issues which directly affects youths. Although this study found out that NYDP comprises some strategies to combat unemployment, yet the policy have lacuna and youths themselves have perceptions that they do have ownership of the document.

\subsection{Recommendations}

The study recommends that for the government and to tackle youth employment following has to be done:-

- Government should adopt strategies that will make a new policy to be owned by youths themselves. These including sensitizing and involving in all processes of formulating new policy.

- The new policy should clearly direct to spearheading the achievement of Sustainable Development Goals 2025. Study noticed that, SDG's has not been mentioned anywhere within this policy.

- It is important for new policy to be translated in Kiswahili which is widely spoken by majority of Tanzanians including youths.

- Due to the challenges associated with accessing and securing formal jobs, the study recommends government to extend social security system in informal jobs which employed majority of youths in Tanzania.

- Youths Empowerments loans should be well reviewed and monitored to ensure youths are well benefited from these initiatives.

\section{References}

i. Chachage C (2008), Does The 'New'National Youth Development Policy Reflect Youth Demands? Journal of Sociology- Department of Sociology, UDSM, 2008.

ii. Cohen, L., Manion, L. \& Keith, M. (2000), Research Methods in Education. London: 11 New Fetter Lane.

iii. Costa, R. \& B. Rijkers. (2011). Gender and rural non-farm entrepreneurship (World Development Report 2012 Background Paper).

iv. Darlington, Y. and Scott, D. (2002) Qualitative research in practice Stories from the field. Open University Press, Buckingham.

v. Dudley, L.SL.S (1964). Africa: A Study in Tropical Development. New York, John Willy\& Sons, Inc., 1964.

vi. Haji, M (2015) Youth employment in Tanzania: Taking stock of the evidence and knowledge gaps; International Development Research Centre and the MasterCard Foundation.

vii. International Labour Organisation Report (2019) CH-1211 Genève 22 | Switzerland.

viii. Kothari, C.R. (2004) Research Methodology Methods and Techniques. 2nd Edition, New Age International Publishers, New Delhi.

ix. Morisset, J., Cunningham, V., \& Mahjabeen, H. (2014). Tanzania fifth economic update: Who wants a job? The magnetic power of cities (working paper 88932). Dar es Salaam: World Bank Tanzania.

x. Ogula, P. A. (2005). Research Methods.Nairobi: CUEA Publications.

xi. Padgett, D.K. (ed.). (2004), The Qualitative Research Experience. Belmont, CA: Wadsworth/Thomson Learning.

xii. Restless Development Report 2016

xiii. Rodgers, R. (1979) 'A Student Affairs Application of the CIPP Evaluation Model', in Kuh, G, Evaluation in Student Affairs.

xiv. Rweyemamu, J. (1973). Underdevelopment and Industrialisation in Tanzania: A Study of Perverse Capitalist Industrial Development. Oxford: Oxford University Press.

xv. Sabarwal, S., K. Terrell, \& E. Bardasi. (2009). How do female entrepreneurs perform? Evidence from three developing regions. World Bank. 
xvi. Silverman D (2011) Qualitative Research 3 $3^{\text {rd }}$ Edition, (London: Sage Publication Ltd.

xvii. Skarstein, R. and Wangwe, S. M. (1986). Industrial Development in Tanzania: Some Critical Issues. Dar es Salaam: Tanzania Publishing House.

xviii. Tanzania Youth Development Policy, 2007

xix. World Bank Report 2018. 